LOCKnEED ma RTIN

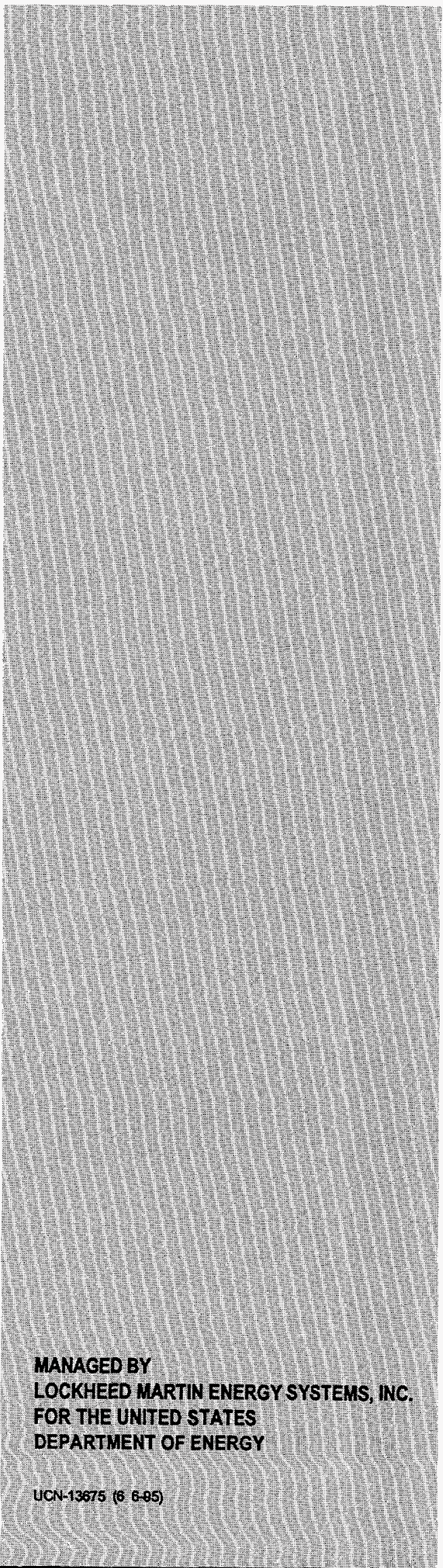

\section{Characterization Summary of Candidate Off-Specification Material for Transfer to the Tennessee Valley Authority}

\author{
Highly Enriched Uranium \\ Disposition Program Office
}

Prepared by the Oak Ridge Y-12 Plant Oak Ridge, Tennessee 37831, managed by Lockheed Martin Energy Systems, Inc., for the U.S. DEPARTMENT OF ENERGY Under contract DE-AC05-84OR21400

DISTRBUTION OF THIS DOCUMENT IS UAYMATED

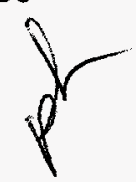




\section{DISCLAIMER}

This report was prepared as an account of work sponsored by an agency of the United States Government. Neither the United States Government nor any agency thereof, nor any of their employees, makes any warranty, express or implied, or assumes any legal liability or responsibility for the accuracy, completeness, or usefulness of any informatior, apparatus, product, or process disclosed, or represents that its use would not infringe privately owned rights. Reference herein to any specific commercial produst, process, or service by trade name, trademark, manu. facturer, or otherwise, does not necessarily constitute or imply its endorsement, recommendation, or favoling by the United States Government or any agency thereof. The views and opinions of authors expressed herein do not necessarily state or reflect those of the United States Government or any agency thereof. 


\section{DISCLAIMER}

Portions of this document may be illegible in electronic image products. Images are produced from the best available original document. 


\section{Characterization Summary of Candidate Off-Specification Material for Transfer to the Tennessee Valley Authority}

Highly Enriched Uranium

Disposition Program Office

January 1998

Prepared by the Oak Ridge Y-12 Plant Oak Ridge, Tennessee 37831, managed by Lockheed Martin Energy Systems, Inc., for the U.S. DEPARTMENT OF ENERGY Under contract DE-AC05-84OR21400 


\section{DISTRIBUTION}

D. N. Bridges, DOE-SR

D. L. Bruner, DOE-SR

T. A. Caritey, DOE-SR

S. O. Cox:

B. G. Eddy, DOE-OR

L. A. Felton

F. P. Gustavson

M. E. Haissler

R. D. Keck

D. L. Mc'Nhorter, WSRC-SR

J. W. Neivton, DOE-DP22

C. E. Olsion, WSRC-SR

J. W. Parks, DOE-OR

K. A. Pilcher

J. D. Stout

D. R. Tousley, DOE-MD4

C. K. Williams, III

T. H. Wynn, DOE-OR

January 7'-8, 1997 TVA Pre-bid Meeting Attendees

HDPO-DMC (RC)

Y-12 Plarit Central Files 


\section{CONTENTS}

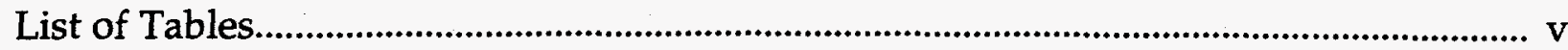

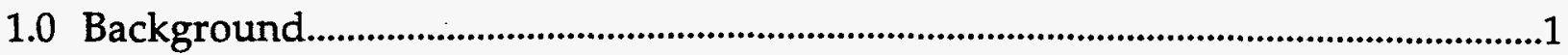

2.0 Type I Material: Off-Spec HEU Uranyl Nitrate from Reprocessed

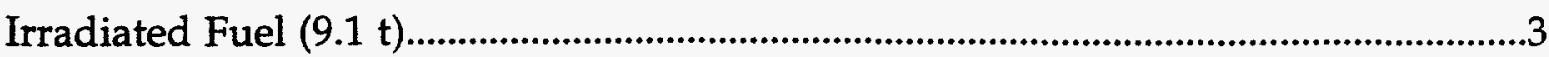

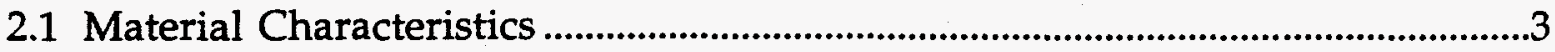

3.0 Type II Material: Off-Spec HEU Uranium-Aluminum Alloy (14.6 t)........................7

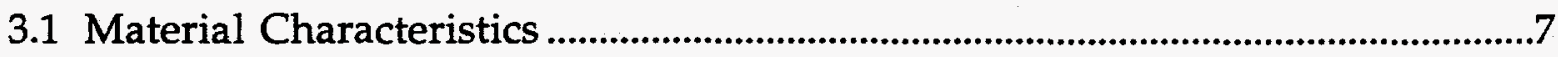

4.0 Type III Material: Off-Spec HEU Unalloyed Metal (9.6 t) .............................................11

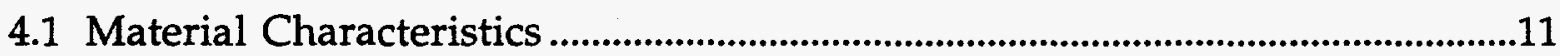

5.0 Type IV Material: Off-Spec HEU Miscellaneous Materials (1.4 t) .............................15

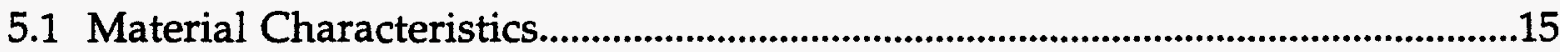

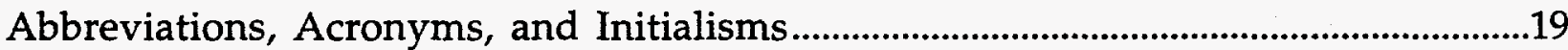

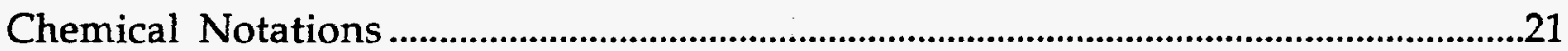

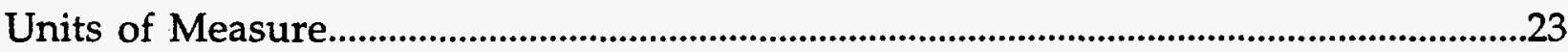

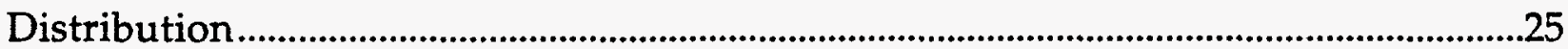


x

This page intentionally left blank.

$\mathbf{z}$

i

F 


\section{LIST OF TABLES}

Table Title

Page

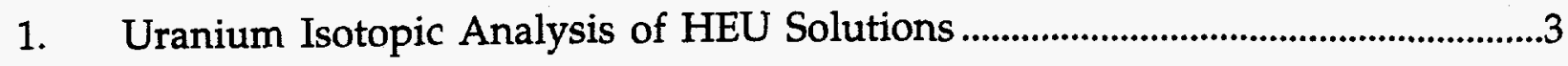

2. Chemical Analysis of HEU Solutions.....................................................................

3. Data for Irradiated HEU Reactor Fuel .......................................................................

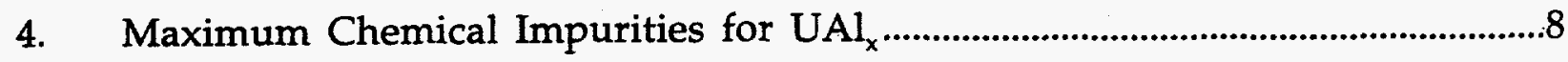

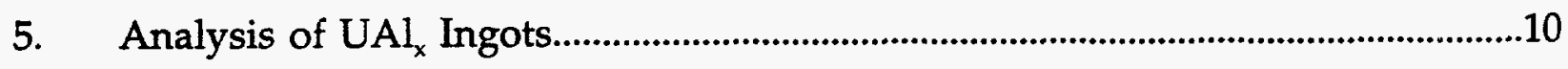

6. Analysis of Unalloyed Metal Buttons......................................................................12

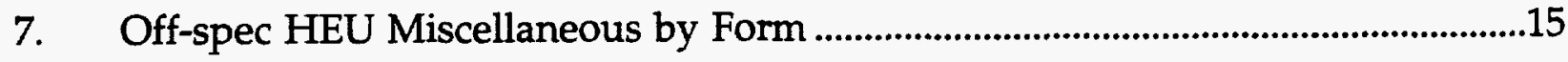

8. Analysis of LUA Material......................................................................................17 
This page intentionally left blank. 


\subsection{BACKGROUND}

The United States Enrichment Corporation (USEC) Privatization Act, Public Law 104-134, Sec. 3112(e)(1), signed April 26, 1996, provides that, prior to privatization, the Department of Energy (DOE) may transfer off-specification (off-spec) enriche $d$ uranium to a federal agency if the material is transferred for the use of the receiving agency without resale or subsequent transfer to another entity. The Tennessee Valley Authority (TVA) has expressed an interest in obtaining some of this off-spec surplus highly enriched uranium (HEU) for the purpose of making fuel for its reactors. Discussions between DOE and TVA over the past two years have resulted in a framework between DOE and TVA within which to develop a program for the utilization of HEU blended to off-spec low-enriched uranium (LEU) for use in TVA commercial nuclear power reactors. A minimum of 30 metric tons uranium ( $t$ ) of HEU has been designated for this program.

DOE has identified material amounting to approximately $35 \mathrm{t}$ that potentially will be transferred to the TVA. This material is located at several domestic HEU processing and storage facilities, both within the DOE and in the private sector. 
This page intentionally left blank.

E

$\mathbf{i}$

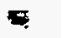




\subsection{TYPE I MATERIAL: OFF-SPEC HEU URANYL NITRATE FROM REPROCESSED IRRADIATED FUEL (9.1 t)}

The Type I material consists of $9.1 \mathrm{t}$ of surplus off-spec HEU, comprised of $1.3 \mathrm{t}$ contained in dilute reprocessing solutions of uranyl nitrate and $7.8 \mathrm{t}$ contained in aluminum-clad alloy ( $\left.\mathrm{UAl}_{\mathrm{x}}\right)$ irradiated reactor fuel. Because of its processing history, all of this material has similar concentrations of uranium isotopes and should have similar elemental concentrations (after reprocessing of the irradiated HEU reactor fuel).

\subsection{Material Characteristics}

HEU Solutions (1.3 $t$ ): This inventory consists of 230,000 liters of dilute uranyl nitrate solutions containing $1.3 \mathrm{t}$ of HEU that remained after reactor fuel reprocessing operations were suspended. The average assay of the HEU in these solutions is 61 percent ${ }^{235} \mathrm{U}$. The uranium isotopic analysis of these HEU solutions is shown in Table 1. The concentration of both ${ }^{234} \mathrm{U}$ and ${ }^{236} \mathrm{U}$ will exceed ASTM specification limits after blending.

Table 1. Uranium Isotopic Analysis of HEU Solutions

\begin{tabular}{|c|c|c|}
\hline Uranium Isotope & \% of Total $\mathrm{U}^{1}$ & Concentration $^{1}$ \\
\hline${ }^{232} \mathrm{U}$ & 0.000002 & $3.3 \times 10^{-2} \mu \mathrm{g} / \mathrm{g}^{235} \mathrm{U}$ \\
\hline${ }^{233} \mathrm{U}$ & 0.01 & $165 \mu \mathrm{g} / \mathrm{g}^{235} \mathrm{U}$ \\
\hline${ }^{234} \mathrm{U}$ & 1.2 & $20,400 \mu \mathrm{g} / \mathrm{g}{ }^{235} \mathrm{U}$ \\
\hline${ }^{235} \mathrm{U}$ & 60.5 & $\mathrm{~N} / \mathrm{A}$ \\
\hline${ }^{236} \mathrm{U}$ & 23.7 & $392,000 \mu \mathrm{g} / \mathrm{g}^{235} \mathrm{U}$ \\
\hline
\end{tabular}

'Obtained from NMC\&A test sample taken in December 1995. 
A chemical analysis of the HEU solutions is shown in Table 2. Because of the processing history, these materials likely contain small amounts of neptunium and plutonium. However, equipment used in the analysis was not adequately sensitive to determine the neptunium and plutonium content. The proposed alpha activity limit for plutonium and neptunium for off-spec LEU is under development. It is likely that the acceptable upper limit will be less than $50 \mathrm{~Bq} / \mathrm{gU}$. However, this material appears to be suitable as off-spec fuel.

Table 2. Chemical Analysis of HEU Solutions

\begin{tabular}{|l|c|}
\hline \multicolumn{1}{|c|}{ Chemical Element } & Concentration $^{1}(\mu \mathrm{g} / \mathrm{gU})$ \\
\hline Aluminum & $<0.4$ \\
\hline Calcium - Magnesium & 10.8 \\
\hline Chromium & $<0.4$ \\
\hline Cobalt & $<1.0$ \\
\hline Iron & 3.6 \\
\hline Nickel & $<0.4$ \\
\hline Plutonium - Neptunium & $>0^{2}$ \\
\hline Silicon & $<2.0$ \\
\hline Thorium & $<3.0$ \\
\hline
\end{tabular}

'Obtained from NMC\&A test sample taken in December 1995.

${ }^{2}$ This material is presumed to contain plutonium and neptunium.

Equipment used in this analysis was not adequately sensitive to determine plutonium content.

HEU Reactor fuel $(7.8 \mathrm{t})$ : This inventory consists of approximately 3,000 irradiated fuel elements. The fuel in these elements is an Al-clad, UAlx alloy. Historically, much of this fuel has been reprocessed many times. No laboratory analyses are available for this irradiated material. However, Table 3 shows the uranium isotopics from 1,896 irradiated fuel elements that have been calculated from reactor batching memoranda that give the isotopic composition of fuel charged to reactors and the fuel exposure at discharge. 
Table 3. Data for Irradiated HEU Reactor Fuel

\begin{tabular}{|l|c|c|c|c|c|c|}
\hline Batch & A & B & C & E & F & G \\
\hline $\begin{array}{l}\text { No. of cycles in } \\
\text { reactor }\end{array}$ & 5 & 2 & 4 & 3 & 2 & 1 \\
\hline $\begin{array}{l}\text { Days fuel cooled } \\
\text { on 01/01/95 }\end{array}$ & 2835 & 2328 & 2735 & 2383 & 2459 & 884 \\
\hline Assemblies & 96 & 432 & 252 & 252 & 432 & 432 \\
\hline \multicolumn{1}{|c|}{ U Isotope, $\%^{1}$} & 1.3 & 1.3 & 1.3 & 1.3 & 1.3 & 1.3 \\
\hline U-234 & 54.8 & 58.8 & 59.2 & 60.0 & 64.2 & 65.8 \\
\hline U-235 & 28.0 & 18.3 & 24.4 & 23.8 & 21.5 & 19.7 \\
\hline U-236 & 15.9 & 21.6 & 15.1 & 14.9 & 13.0 & 13.2 \\
\hline U-238 &
\end{tabular}

'Information on a total of 1896 fuel elements (assemblies) is presented in this 1995 table. Current records list 1883 fuel elements available.

Isotopic and trace element data from the $1.3 \mathrm{t}$ in uranyl nitrate solution form (see Tables 1 and 2) is used to represent the expected chemical composition of the $7.8 \mathrm{t}$ of reactor fuel after it has been processed. This assumption is reasonable since the $7.8 \mathrm{t}$ of reactor fuel will be processed similar to the manner in which $1.3 \mathrm{t}$ in solution form was processed. The HEU solutions (previously described) are derived from chemically processing Al-clad, $\mathrm{UAl}_{\mathrm{x}}$ alloy reactor fuel. Therefore, the chemical composition of the HEU derived from this reactor fuel, when chemically processed, is expected to be similar. 
1

This page intentionally left blank.

$\Sigma$

$i$

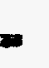




\subsection{TYPE II MATERIAL: OFF-SPEC HEU URANIUM-ALUMINUM ALLOY (14.6 t)}

The Type II material consists of $14.6 \mathrm{t}$ of $\mathrm{UAl}_{\mathrm{x}}$ alloy. The $\mathrm{UAl}_{\mathrm{x}}$ is material that has been irradiated, reprocessed, blended with higher assay HEU to increase enrichment, and fabricated into $\mathrm{UAl}_{\mathrm{x}}$ alloy (nominally 25 percent uranium and 75 percent aluminum) for subsequent fabrication of new fuel elements. This material has not been irradiated since it was last reprocessed.

\subsection{Material Characteristics}

$\mathrm{UAl}_{\mathrm{x}}$ alloy: The $\mathrm{UAl}_{\mathrm{x}}$ material consists of a combination of $\mathrm{UAl}_{\mathrm{x}}$ ingots and fresh reactor fuel elements. There are approximately 7,900 ingots and 3,100 reactor fuel elements. The ingots were produced by melting and casting a variety of the types of the reactor fuel elements. The net weight of ingots averages about $5 \mathrm{kgs}$ each and the net weight of the larger-sized fuel elements averages around $12 \mathrm{kgs}$ each. The larger fuel elements consist of approximately 44 percent 8001 Aluminum, 33 percent pure (99.99 percent) Aluminum, 7 percent 5052 Aluminum, and 16 percent HEU metal. Table 4 shows approximate maximum impurities for the larger fuel elements and the $\mathrm{UAl}_{\mathrm{x}}$ ingots. These impurity values are calculated from process specifications and may not be fully representative of all of the $\mathrm{UAl}_{\mathrm{x}}$ material. The information is provided for reference only. 
Table 4. Maximum Calculated Chemical Impurities for $\mathrm{UAl}_{\mathrm{x}}$

\begin{tabular}{|c|c|c|}
\hline & \multicolumn{2}{|c|}{ Max. Impurities per Item (gms) } \\
\hline Contaminant & $\begin{array}{l}\text { Larger Fuel } \\
\text { Element }\end{array}$ & Ingot \\
\hline Antimony & 0.08 & 0.06 \\
\hline Beryllium & 0.06 & 0.06 \\
\hline Boron & 0.12 & 0.10 \\
\hline Cadmium & 0.33 & 0.27 \\
\hline Calcium & 0.20 & 0.19 \\
\hline Carbon & 1.20 & 1.12 \\
\hline Chromium & 2.80 & 0.68 \\
\hline Cobalt & 0.12 & 0.10 \\
\hline Copper & 9.10 & 8.94 \\
\hline Iron & 42.00 & 40.21 \\
\hline Lithium & 0.84 & 0.70 \\
\hline Magnesium & 40.40 & 5.81 \\
\hline Manganese & 1.00 & 1.57 \\
\hline Nickel & 71.00 & 64.84 \\
\hline Silicon & 12.38 & 11.54 \\
\hline Sodium & 0.05 & 0.05 \\
\hline Zinc & 3.50 & 4.17 \\
\hline Others & 9.30 & 8.42 \\
\hline Total & 194.48 & 148.83 \\
\hline
\end{tabular}

Note: The weight of each constituent was multiplied by the maximum acceptable weight percent of various items permitted in the specification. 
As with the other off-spec $\mathrm{HEU}$, the $\mathrm{UAl}_{\mathrm{x}}$ material requires conversion into a readily usable form for LEU commercial reactor fuel. The exact processing methodology will depend upon the blending process utilized. In the past, HEU has been recovered from this type of alloy by first dissolving the alloy in $\mathrm{NaOH}$ solution, filtering the solution to capture the insoluble uranium compound, dissolving the solids in nitric acid, purifying the resultant uranyl nitrate solution by solvent extraction, evaporating the purified solution, denitrating to $\mathrm{UO}_{3}$, reducing the $\mathrm{UO}_{3}$ with hydrogen to make $\mathrm{UO}_{2}$, hydrofluorinating to $\mathrm{UF}_{4}$, and reducing the $\mathrm{UF}_{4}$ with calcium to make pure uranium buttons.

A portion of the ingot material has been analyzed for purity and isotopic abundance. Averages of the analyses of $2.6 \mathrm{t}$ of $\mathrm{UAl}_{x}$ alloy ingots are provided in Table 5.

The uranium isotopic concentrations vary slightly between individual batches, with average concentrations at 19.9 percent ${ }^{236} \mathrm{U}, 1.2$ percent ${ }^{234} \mathrm{U}$, 66 percent ${ }^{235} \mathrm{U}$, and 13.4 percent ${ }^{238} \mathrm{U}$. Chemical purity between individual batches vary by a factor of two. It is therefore assumed that the aluminum content of the alloy ranges from 70 to 85 percent. The concentration of ${ }^{232} \mathrm{U}$ and transuranics in this material should be similar to uranium metal buttons (refer to the Type III material section). 
Table 5. Analyses of $\mathrm{UAl}_{\mathbf{x}}$ Ingots

\begin{tabular}{|c|c|c|c|c|c|}
\hline \multirow[b]{2}{*}{$\begin{array}{l}\text { Avg. Ingot } \\
\text { Net Wgt (g) }\end{array}$} & \multirow[b]{2}{*}{$\begin{array}{l}\text { No. of } \\
\text { Ingots }\end{array}$} & \multirow[b]{2}{*}{ Avg. Purity } & \multicolumn{3}{|c|}{ Avg. U Isotope Abundances (wt \%) } \\
\hline & & & ${ }^{234} \mathrm{U}$ & ${ }^{235} \mathrm{U}$ & ${ }^{236} \mathrm{U}$ \\
\hline 5458 & 96 & .2935 & 1.18 & 65.82 & 19.81 \\
\hline 5503 & 96 & .3047 & 1.18 & 65.97 & 19.71 \\
\hline 5305 & 96 & .2927 & 1.19 & 69.70 & 19.91 \\
\hline 5428 & 96 & .2978 & 1.19 & 66.06 & 19.67 \\
\hline 5564 & 96 & .2996 & 1.20 & 65.27 & 20.25 \\
\hline 5485 & 96 & .3013 & 1.19 & 65.84 & 19.84 \\
\hline 5467 & 96 & .2922 & 1.19 & 65.77 & 19.84 \\
\hline 5245 & 96 & .3022 & 1.19 & 65.21 & 20.19 \\
\hline 5663 & 96 & .3193 & 1.21 & 64.18 & 21.08 \\
\hline 5438 & 96 & .2899 & 1.18 & 65.89 & 19.75 \\
\hline 5256 & 96 & .3169 & 1.18 & 65.94 & 19.75 \\
\hline 5076 & 96 & .2652 & 1.21 & 63.11 & 21.79 \\
\hline 4795 & 96 & .1549 & 1.17 & 65.48 & 19.69 \\
\hline 4672 & 96 & .1608 & 1.17 & 65.96 & 19.41 \\
\hline 4681 & 96 & .1530 & 1.17 & 65.28 & 19.79 \\
\hline 4962 & 96 & .1600 & 1.17 & 65.04 & 20.00 \\
\hline 5132 & 96 & .1715 & 1.17 & 64.59 & 20.25 \\
\hline 5171 & 96 & .1713 & 1.15 & 66.03 & 19.20 \\
\hline 5046 & 96 & .1621 & 1.17 & 64.91 & 19.98 \\
\hline 5068 & 96 & .1676 & 1.16 & 64.41 & 18.62 \\
\hline 5073 & 96 & .1714 & 1.18 & 65.34 & 19.70 \\
\hline
\end{tabular}




\subsection{TYPE III MATERIAL: OFF-SPEC HEU UNALLOYED METAL (9.6 $t)$}

The Type III material consists of $9.6 \mathrm{t}$ of HEU in the form of pure metal buttons. These metal buttons were the feed stream to the same HEU fuel fabrication process that produced the $\mathrm{UAl}_{\mathrm{x}}$ alloy described in the previous section. On average, these buttons contain about $4.5 \mathrm{kgU}$ each.

\subsection{Material Characteristics}

The uranium isotopic concentrations vary slightly between individual buttons, with average concentrations at 1.3 percent ${ }^{234} \mathrm{U}, 55.0$ percent ${ }^{235} \mathrm{U}$, and 27.6 percent ${ }^{236} \mathrm{U}$. It is assumed that the remainder is ${ }^{238} \mathrm{U}$. Recent health physics surveys on 30 storage containers (each containing four buttons) measured surface activity on the containers ranging up to $100 \mathrm{mr} / \mathrm{hr} .^{\mathrm{i}}$ Measured radiation levels $30 \mathrm{~cm}$ away from containers range between 15 and $20 \mathrm{mr} / \mathrm{hr}$.

Approximately 560 samples of this material have been analyzed for isotopic abundance and chemical impurities. The results, given in Table 6, reflect the actual characteristics of 88 percent of the $9.6 \mathrm{t}$ inventory of this material. 
Table 6. Analyses of Unalloyed Metal Buttons

\begin{tabular}{|c|c|c|c|c|}
\hline Element & Units & Mean & Minimum & Maximum \\
\hline Uranium & wt \% & 99.9409 & 99.3450 & 99.9562 \\
\hline U-232 & $\mu \mathrm{g} / \mathrm{gU}$ & 0.0202 & 0.0113 & 0.0287 \\
\hline U-234 & wt. $\%$ & 1.28 & 1.2 & 1.5 \\
\hline U-235 & wt. \% & 55.46 & 45.19 & 64.87 \\
\hline $\mathrm{U}-236$ & wt. \% & 28.13 & 20.41 & 36.41 \\
\hline $\mathrm{U}-238$ & wt. \% & 16.27 & 13.46 & 20.16 \\
\hline $\mathrm{Np} / \mathrm{Pu}$ & $\mathrm{Bg} / \mathrm{gU}$ & 198.15 & 20.33 & $1,003.33$ \\
\hline $\mathrm{Al}$ & $\mathrm{ppm}$ & 20.6 & 1 & 120 \\
\hline As & $\mathrm{ppm}$ & $<10$ & $*$ & * \\
\hline $\mathrm{Au}$ & $\mathrm{ppm}$ & $<1$ & $*$ & $*$ \\
\hline B & $\mathrm{ppm}$ & 0.47 & 0.1 & 5.6 \\
\hline $\mathrm{B} \mathrm{a}$ & $\mathrm{ppm}$ & 2.01 & 0.1 & 12 \\
\hline $\mathrm{Be}$ & $\mathrm{ppm}$ & 0.11 & 0.1 & 2 \\
\hline $\mathrm{Bi}$ & $\mathrm{ppm}$ & 1.02 & 1 & 4 \\
\hline$C$ & $\mathrm{ppm}$ & 117 & 35 & 315 \\
\hline $\mathrm{Ca}$ & ppm & 17.6 & 10 & 406 \\
\hline $\mathrm{Cd}$ & ppm & 0.121 & 0.1 & 0.5 \\
\hline $\mathrm{Co}$ & ppm & 1.10 & 1 & 5 \\
\hline $\mathrm{Cr}$ & ppm & 9.40 & 0.1 & 41 \\
\hline $\mathrm{Gu}$ & ppm & 7.6 & 1 & 184 \\
\hline $\mathrm{Fe}$ & ppm & 40.8 & 11 & 345 \\
\hline $\mathrm{Ga}$ & $\mathrm{ppm}$ & $<1$ & $*$ & $*$ \\
\hline $\mathrm{Ge}$ & $\mathrm{ppm}$ & $<1$ & $*$ & $*$ \\
\hline $\mathrm{Li}$ & ppm & 0.37 & 0.1 & 4.5 \\
\hline $\mathrm{Mg}$ & ppm & 16.5 & 1 & 87 \\
\hline $\mathrm{Mn}$ & ppm & 5.39 & 1 & 22 \\
\hline Mo & $\mathrm{ppm}$ & $<10$ & * & * \\
\hline $\mathrm{Na}$ & $\mathrm{ppm}$ & 1.08 & 1 & 40 \\
\hline $\mathrm{Nb}$ & ppm & 14.6 & 10 & 51 \\
\hline $\mathrm{Ni}$ & $\mathrm{ppm}$ & 16.5 & 1 & 146 \\
\hline$\underline{P}$ & $\mathrm{ppm}$ & $<100$ & $*$ & * \\
\hline $\mathrm{Pb}$ & ppm & 4.46 & 4 & 10 \\
\hline $\mathrm{Pd}$ & $\mathrm{ppm}$ & $<1$ & $*$ & $*$ \\
\hline $\mathrm{s}$ & ppm & $<2$ & $*$ & $*$ \\
\hline $\mathrm{Sb}$ & $\mathrm{ppm}$ & $<2$ & * & * \\
\hline $\mathrm{Si}$ & $\mathrm{ppm}$ & 22.8 & 10 & 347 \\
\hline $\mathrm{Sn}$ & ppm & 10.02 & 10 & 19 \\
\hline $\mathrm{Sr}$ & $\mathrm{ppm}$ & $<20$ & * & $*$ \\
\hline $\mathrm{Ti}$ & ppm & 4.5 & 4 & 34 \\
\hline $\mathrm{V}$ & $\mathrm{ppm}$ & 1.35 & .07 & 9 \\
\hline$W$ & $\mathrm{ppm}$ & $<100$ & $*$ & $*$ \\
\hline $\mathrm{Zn}$ & ppm & $<10$ & $*$ & * \\
\hline
\end{tabular}

*Indicates that values are equal to the mean item value. 
Data suggest that these metal buttons will not require additional purification before blending. A few samples show high levels of neptunium and plutonium, but the mean value for these contaminants is well below the proposed limit. Individual lots with high levels of plutonium and neptunium might be handled by blending with other lots having much lower levels. Total gamma activity was not reported, but the ${ }^{232} \mathrm{U}$ concentrations were about 1 percent of the level that would be required for decay of ${ }^{232} \mathrm{U}$ and its daughters to exceed the ASTM specification limit on gamma from reprocessed uranium. The non-radioactive elements present were all at concentrations below the proposed specification. 
This page intentionally left blank.

$E$

$\pi$

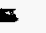

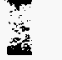

-

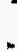




\subsection{TYPE IV MATERIAL: OFF-SPEC HEU MISCELLANEOUS MATERIALS (1.4 t)}

The Type IV material consists $1,378 \mathrm{kgU}$ of miscellaneous materials in forms such as floor sweepings and process residues. The materials in the miscellaneous category have a similar processing history to the Type II material. This material is included because it completes the inventory of this same processing history material. However, some of this material is not immediately available and will require processing prior to packaging and shipment.

\subsection{Material Characteristics}

Table 7 presents a summary of the miscellaneous materials by form.

Table 7. Off-Spec HEU Miscellaneous by Form

\begin{tabular}{|l|c|}
\hline \multicolumn{1}{|c|}{ Materials } & Total (kgU) \\
\hline Misc. - Solids & 551.8 \\
\hline Metal - Alloyed Scrap & 404.4 \\
\hline Oxide - Other & 165.3 \\
\hline Oxide - UO ${ }_{3}$ & 152.1 \\
\hline Solutions - Aqueous & 36.6 \\
\hline Compounds - UF & 35.5 \\
\hline Sources \& Standards - Standards & 12.4 \\
\hline Solutions - Organic & 11.4 \\
\hline Oxide - $\mathrm{U}_{3} \mathrm{O}_{8}$ & 3.9 \\
\hline Misc. Equip Holdup & 2.6 \\
\hline Sources \& Standards - Samples & 0.6 \\
\hline Misc. - Discard & 0.3 \\
\hline Compounds - UNH & 0.3 \\
\hline Misc. - Other & 0.2 \\
\hline Combustibles - Other & 0.2 \\
\hline & $1,377.6$ \\
\hline Total & \\
\hline
\end{tabular}

Note: Totals may not sum due to rounding. 
The $404.4 \mathrm{kgU}$ of alloyed metal scrap is the inventory of surplus HEU originally reserved for TVA's lead use assemblies (LUA) for the demonstration. The uranium isotopic concentrations in this material is 66 percent ${ }^{235} \mathrm{U}, 19$ percent ${ }^{236} \mathrm{U}, 1.2$ percent ${ }^{234} \mathrm{U}, 10 \mathrm{ppm}{ }^{233} \mathrm{U}$, and $20 \mathrm{ppb}{ }^{232} \mathrm{U}$. The remainder, approximately 14 percent, is ${ }^{238} \mathrm{U}$.

Three samples of this $404.4 \mathrm{kgU}$ inventory have been purified (through a laboratory-scale solvent extraction process), combined, and analyzed. The results are provided in Table: 8 . Because of sampling techniques, the solvent extraction process utilized, and sensitivity of the analytical equipment, this sample may not accurately represent LEU derived from this miscellaneous HEU. Therefore, Table 8 is included for information purposes.

Excepting the $404.4 \mathrm{kgU}$ of material in the TVA LUAs, other miscellaneous materials have not been adequately characterized. These materials exist in a variety of forms including irnpure oxides, crucible "skull" oxide, trichlorethane oil, ceramic crucibles, concentrated nitrate solutions, dilute nitrate solutions, carbitol and tri-butyl phosphate, tetrafluoride, clinkers and screenings, ash and other unleached solids, and discard solids. The ${ }^{235} \mathrm{U}$ assay of these materials ranges from 50 to 85 percent. Other uranium isotope concentrations vary widely. In general, these miscellaneous HEU materials will need to be purified and converted to suitable forms such as oxide compounds or metal. 
Table 8. Analysis of LUA Material

\begin{tabular}{|c|c|c|}
\hline Element & Unit & Results \\
\hline${ }^{238} \mathrm{Pu}$ & $\mathrm{pCi} / \mathrm{g}$ & $<12,900$ \\
\hline${ }^{239} \mathrm{Pu}$ & $\mathrm{pCi} / \mathrm{g}$ & $<12,900$ \\
\hline${ }^{232} \mathrm{U}$ & $\mathrm{pCi} / \mathrm{g}$ & 300,000 \\
\hline${ }^{234} \mathrm{U}$ & wt \%. & 1.18 \\
\hline${ }^{235} \mathrm{U}$ & wt $\%$ & 63.78 \\
\hline${ }^{236} \mathrm{U}$ & wt. \% & 20.20 \\
\hline${ }^{238} \mathrm{U}$ & wt. \% & 14.83 \\
\hline${ }^{99} \mathrm{Tc}$ & $\mu \mathrm{g} / \mathrm{g}^{235} \mathrm{U}$ & 0.06 \\
\hline $\mathrm{Al}$ & ppm U basis & $>500$ \\
\hline $\mathrm{Sb}$ & ppm U basis & $<3$ \\
\hline As & ppm U basis & $<5$ \\
\hline B & ppm U basis & 0.68 \\
\hline $\mathrm{Br}$ & ppm U basis & $<2.5$ \\
\hline $\mathrm{Cl}$ & ppm U basis & 20 \\
\hline $\mathrm{Cr}$ & ppm U basis & $<3$ \\
\hline $\mathrm{Gd}$ & ppm U basis & $<0.2$ \\
\hline $\mathrm{Sm}$ & ppm U basis & $<0.2$ \\
\hline Dy & ppm U basis & $<0.2$ \\
\hline Eu & ppm U basis & $<0.2$ \\
\hline Mo & ppm U basis & $<2.0$ \\
\hline $\mathrm{Nb}$ & ppm U basis & $\mathrm{n} / \mathrm{a}$ \\
\hline$P$ & ppm U basis & 230 \\
\hline $\mathrm{Ru}$ & ppm U basis & $\mathrm{n} / \mathrm{a}$ \\
\hline $\mathrm{Ta}$ & ppm U basis & $\mathrm{n} / \mathrm{a}$ \\
\hline $\mathrm{Ti}$ & ppm U basis & $<50$ \\
\hline W & ppm U basis & $n / a$ \\
\hline $\mathrm{V}$ & ppm U basis & $<5$ \\
\hline $\mathrm{Zr}$ & ppm U basis & $\mathrm{n} / \mathrm{a}$ \\
\hline $\mathrm{Hg}$ & ppm total weight basis & 8.5 \\
\hline
\end{tabular}

(1) The data for the enrichment and mercury is a weighted calculation from the results of the three feed samples. All other values were obtained on a sample of oxide generated from a composite of the three feed samples.

(2) $\mathrm{The}{ }^{222} \mathrm{U},{ }^{99} \mathrm{Tc}, \mathrm{Br}$, and $\mathrm{Cl}$ numbers are on a best-effort basis. These analyses were done without an actual procedure but were analyzed by supervisors using established protocol.

(3) The high $\mathrm{Al}$ and $\mathrm{P}$ numbers are most likely due to carryover from the solvent extraction process in the lab and do not represent levels expected in a uranium recovery facility. 
This page intentionally left blank.

$\Sigma$

$\mathbf{i}$

I 


\section{ABBREVIATIONS, ACRONYMS, AND INITIALISMS}

$\begin{array}{ll}\text { ASTM } & \text { American Society for Testing and Materials } \\ \text { CADS } & \text { Characterization Analysis Database System } \\ \text { DOE } & \text { Department of Energy } \\ \text { HEU } & \text { highly enriched uranium } \\ \text { LEU } & \text { low-enriched uranium } \\ \text { LUA } & \text { lead use assembly } \\ \text { MOU } & \text { memorandum of understanding } \\ \text { NMC\&A } & \text { nuclear materials control and accountability } \\ \text { NRC } & \text { Nuclear Regulatory Commission } \\ \text { TVA } & \text { Tennessee Valley Authority } \\ \text { UAl } & \text { Uranium-Aluminum Alloy } \\ \text { USEC } & \text { United States Enrichment Corporation }\end{array}$


This page intentionally left blank.

$\overrightarrow{3}$

$\mathbf{E}$

E

x

.

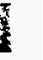




\section{CHEMICAL NOTATIONS}

\begin{tabular}{|c|c|c|c|}
\hline $\mathrm{Al}$ & aluminum & As & arsenic \\
\hline $\mathrm{Au}$ & gold & B & boron \\
\hline $\mathrm{Ba}$ & barium & $\mathrm{Be}$ & beryllium \\
\hline $\mathrm{Bi}$ & bismuth & $\mathrm{Br}$ & bromine \\
\hline $\mathrm{C}$ & carbon & $\mathrm{Ca}$ & calcium \\
\hline $\mathrm{Cd}$ & cadmium & $\mathrm{Cl}$ & chlorine \\
\hline${ }^{36} \mathrm{Cl}$ & chlorine isotope 36 & Co & cobalt \\
\hline $\mathrm{Cr}$ & chromium & Cs & cesium \\
\hline${ }^{135} \mathrm{Cs}$ & cesium isotope 135 & ${ }^{137} \mathrm{Cs}$ & cesium isotope 137 \\
\hline $\mathrm{Cu}$ & copper & Dy & dysprosium \\
\hline $\mathrm{Eu}$ & europium & $\mathrm{Fe}$ & iron \\
\hline $\mathrm{Ga}$ & gallium & $\mathrm{Gd}$ & gadolinium \\
\hline Ge & germanium & $\mathrm{Hg}$ & mercury \\
\hline $\mathrm{Li}$ & lithium & $\mathrm{Mg}$ & magnesium \\
\hline $\mathrm{MgF}_{2}$ & magnesium fluoride & Mn & manganese \\
\hline Mo & molybdenum & $\mathrm{Na}$ & sodium \\
\hline $\mathrm{NaF}$ & sodium fluoride & $\mathrm{NaOH}$ & sodium hydroxide \\
\hline $\mathrm{Nb}$ & niobium & $\mathrm{Ni}$ & nickel \\
\hline${ }^{59} \mathrm{Ni}$ & nickel isotope 59 & ${ }^{63} \mathrm{Ni}$ & nickel isotope 63 \\
\hline $\mathrm{Np}$ & neptunium & ${ }^{237} \mathrm{~Np}$ & neptunium isotope 237 \\
\hline$P^{2}$ & phosphorus & ${ }^{231} \mathrm{~Pa}$ & protactinium isotope 231 \\
\hline $\mathrm{Pb}$ & lead & $\mathrm{Pd}$ & palladium \\
\hline $\mathrm{Pu}$ & plutonium & ${ }^{238} \mathrm{Pu}$ & plutonium isotope 238 \\
\hline${ }^{239} \mathrm{Pu}$ & plutonium isotope 239 & $\mathrm{PuO}_{2}$ & plutonium dioxide \\
\hline $\mathbf{R u}$ & ruthenium & $\mathrm{S}$ & sulfur \\
\hline $\mathrm{Sb}$ & antimony & Se & selenium \\
\hline $\mathrm{Si}$ & silicon & Sm & samarium \\
\hline $\mathrm{Sn}$ & tin & $\mathrm{Sr}$ & strontium \\
\hline${ }^{89} \mathrm{Sr}$ & strontium isotope 89 & ${ }^{90} \mathrm{Sr}$ & strontium isotope 90 \\
\hline $\mathrm{Ta}$ & tantalum & $\mathrm{Tc}$ & technetium \\
\hline${ }^{99} \mathrm{Tc}$ & technetium isotope 99 & $\mathrm{Ti}$ & titanium \\
\hline $\mathrm{U}_{3} \mathrm{O}_{8}$ & triuranium octaoxide & $\mathrm{UAl}_{\mathrm{x}}$ & uranium-aluminum alloy \\
\hline UNH & uranyl nitrate hexahydrate & $\mathrm{UF}_{4}$ & uranium tetrafluoride \\
\hline $\mathrm{UF}_{6}$ & uranium hexafluoride & $\mathrm{UO}_{2}$ & uranium dioxide \\
\hline $\mathrm{UO}_{2}\left(\mathrm{NO}_{3}\right)_{2}$ & uranyl nitrate & $\mathrm{UO}_{3}$ & uranium trioxide \\
\hline${ }^{232} \mathrm{U}$ & uranium isotope 232 & ${ }^{233} \mathrm{U}$ & uranium isotope 233 \\
\hline${ }^{234} \mathrm{U}$ & uranium isotope 234 & ${ }^{235} \mathrm{U}$ & uranium isotope 235 \\
\hline${ }^{236} \mathrm{U}$ & uranium isotope 236 & ${ }^{238} \mathrm{U}$ & uranium isotope 238 \\
\hline V & vanadium & W & tungsten \\
\hline Zn & zinc & $\mathrm{Zr}$ & zirconium \\
\hline
\end{tabular}





\section{UNITS OF MEASURE}

$\begin{array}{ll}\mathrm{Bq} / \mathrm{gU} & \text { becquerels per gram of uranium } \\ \mathrm{cm} & \text { centimeter } \\ \mathrm{dpm} / \mathrm{g} & \text { disintegrations per minute per gram of material } \\ \mathrm{gms} & \text { grams } \\ \mathrm{kgU} & \text { kilogram of uranium } \\ \mu \mathrm{g} & \text { microgram } \\ \mathrm{mg} / \mathrm{g} & \text { milligrams per gram of material } \\ \mathrm{mr} / \mathrm{hr} & \text { millirems per hour } \\ \mathrm{pCi} / \mathrm{g} & \text { picocuries per gram } \\ \mathrm{ppb} & \text { parts per billion on a weight basis } \\ \mathrm{ppm} & \text { parts per million on a weight basis } \\ \mathrm{t} & \text { metric ton of uranium } \\ \% & \text { weight-\% (when used to specify an isotopic assay) }\end{array}$


This page intentionally left blank.

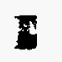

[?

臬 


\section{DISTRIBUTION}

D. N. Bridges, DOE-SR

D. L. Bruner, DOE-SR

T. A. Cantey, DOE-SR

S. O. Cox

B. G. Eddy, DOE-OR

L. A. Felton

F. P. Gustavson

M. E. Hassler

R. D. Keck

D. L. McWhorter, WSRC-SR

J. W. Newton, DOE-DP22

C. E. Olson, WSRC-SR

J. W. Parks, DOE-OR

K. A. Pilcher

J. D. Stout

D. R. Tousley, DOE-MD4

C. K. Williams, III

T. H. Wynn, DOE-OR

January 7-8, 1997 TVA Pre-bid Meeting Attendees HDPO-DMC (RC)

Y-12 Plant Central Files 